\title{
Historical Geography and International Boundaries
}

\section{GIDEON BIGER}

Department of Geography and Human Environment, Faculty of Exact Science, Tel-Aviv University, Ramat-Aviv, Tel-Aviv 6997801, Israel. Email: bigergideon@ gmail.com

International boundaries are man-made separation lines. All of today's boundaries were created in the past, sometimes years, sometimes decades, even in some cases centuries ago. Thus, international boundaries reflect the historical moments in the life of a State, when its limits were made according to its force and ability at a given time. Understanding the process of boundary making and the location of boundaries can become a bridge of research and knowledge between three major scientific areas - history, geography and political science.

Historical geography deals with past geography, with geographical processes that took place in the past, with the influence of historical events on the landscape, and with relics of the past that continue to exist in the present landscape. Some of the most important 'relics' are international boundaries. International boundaries are manmade separation lines (Prescott 1978), which currently divide more than 200 different states all over the globe (Biger 1995). These boundaries were described a hundred years ago by Lord Curzon of Kedleston (Curzon 1907), later British Foreign Secretary, as: 'The razor's edge on which hang suspended the modern issues of war and peace, of life or death to nations'. All of today's boundaries were created in the past; sometimes years and sometimes decades ago, and some boundaries even earlier, such as the boundary between France and Spain, established in 1659, or the Mexican-US boundary (Rebert 2001), established in 1853-1854. Thus, international boundaries reflect specific historical moments in the life of a state, according to its power and ability at the time. International boundaries, their history, location, disputes concerning their exact delimitation, their strategic importance, as well as other facts led many scholars to deal with this important subject. International lawyers, geographers, historians, political scientists, researchers of international relations, cartographers, military people, all are concerned with the location of a boundary, its legal status, its history, its defensible ability and so on (Schofield et al. 2002). 
Of the many criteria for establishing a boundary line, the ethnic criteria are those most frequently applied in modern times (Clarke 2002, 259-268), while in the past prominent physical features in the landscape were usually more important. Ethnic boundaries were created in order to separate culturally homogeneous peoples, so that a minimum of stress would be placed upon them (Waterman 2002, 57-76). Because of the world's heterogeneous population, however, it was not always possible to draw boundaries that completely and exactly separate different peoples. As a result, there are ethnic minorities in virtually every country. The definition of a group of people as a 'nation', according to race, language or religion, was used in several cases, especially in post-First World War Europe, when the boundaries of the new states of Estonia, Latvia, Lithuania, Poland, Czechoslovakia and Yugoslavia were marked mainly according to these criteria. Historical geography research, dealing with the historical moment in which a boundary was established, can present the human geographical reasons for such an establishment, which sometimes merely took into account the location of railway lines (Turkey-Syria boundary) or even village boundaries (Biger 2002, 463-472).

Other political boundaries are physiographic boundaries, following rivers (the Odra [Oder] - Nyssa [Neisse] boundary between Poland and Germany established after the Second World War), mountain ranges (the Andes range between Chile and Argentina) or escarpments. Such borders are sometimes termed 'natural boundaries'. These boundaries seem to be especially acceptable criteria, since such pronounced physical features often also separate culturally distinct areas. In the early days of boundary establishment, physiographic features were useful as they could be visually recognized and were considered easy to defend against outside aggression. However, many of the boundary lines based on such physiographic features have created major difficulties between states. Rivers may shift their course and undergo changes in width, depth and length, changes that led to countless disputes over whether the boundary should best be along one of the banks of a river, along the main navigation channel, through the median line of the water's surface, or somewhere else, at the time it was established. This is the case with the boundary between the United States and Mexico established along the Rio Grande (Rio Bravo) river, the course of which shifted over time, causing a 100-year-long dispute between the two countries.

Boundaries could also be located according to physical features that later changed their location. Such was the case with the British Palestine (now partly Israel) - Syria boundary line, which runs $10 \mathrm{~m}$ east of the water level of the Sea of Galilee (Biger 2004). In 1923, when the boundary was established, the water level was $208 \mathrm{~m}$ below sea level. This level is now about $213 \mathrm{~m}$ below sea level, creating a $10 \mathrm{~m}$ line in an unknown, ever-changing place. Other physiographic problems are those of mountain range boundaries. Each mountain range has a recognized crest line, but these lines rarely coincide with the region's watershed. Placing boundaries along crest lines in mountainous areas (for instance the France-Spain boundary along the Pyrenean range) has therefore led to water disputes concerning the use of rivers near their source. 
Moreover, most of today's political boundaries were established in the past by European empires, directly or as arbitrators. In fact, it is difficult to identify any international boundary that has not directly involved a European country at some stage of its historical evolution. As most of today's boundaries were established during the last 200 years, they reflect the European hegemony in the world during the period from 1750 to 1950 . Although most boundaries are now acceptable, there are still a great many (over 100) unresolved boundary and territorial disputes around the world (Brunet-Jailly 2015).

\section{Nation States versus Multinational States}

The majority of independent states today are based on their national character. Back in 1975, Muir (1975, 88-89), after Minogue (1967), outlined three forms of nationalism related to the existence of a nation state (originally there were six, but the other three do not play within a given state):

1. Ante-state nationalism, which developed before becoming a nation state.

2. Post-state nationalism which developed from the integration of diverse cultures cocooned within an existing state.

3. Third-world nationalism, which is the nationalism of peoples who came together under a programme of resistance to colonialism.

As most new countries emerged from the collapse of past empires, the first and the third categories can usefully be merged into one. Thus, a worldwide view can present two main models for the relation between nations and states. One is a EuropeanAsian (the Old World) model and the other is the American-African (the New World) model. As one of the main characteristics of a modern state is that international boundaries mark its territorial sovereignty, one can label this nation-state model the nation-boundaries model.

\section{The Nation-Boundaries Model}

Two simple situations can describe the relation between nations and boundaries. The first presents the classical nation-state, where a nation existed long before its state's international boundary is demarcated. The latter's location aims to include as much as possible of the people of the nation concerned inside the boundaries of the independent state. The second case represents a situation in which the demarcation of the boundary is the basic force in creating a nation. In this situation, a new state is formed, with boundaries that have nothing to do with the initial dispersion of tribes, peoples or nations. The inhabitants of the particular political area, then, through a long process have become a nation that never existed before.

\section{The Nation-Before-Boundary Model}

Examples of the 'nation before boundaries' situation are Poland, as the country of the Polish nation, or Sweden and Thailand, as the countries of the Swedish or Thai 
nations. In a worldwide view, this model applies mainly to the Euro-Asian continent. The Old World, Europe, which will be discussed later, is basically a nation-states continent. Most of Asia's independent states fit this pattern too. Thus, Japan is the country of the Japanese nation, and China is that of the Chinese nation, with some minorities. The Laotian and Cambodian nations, as well as the Uzbek and the Kazakh nations, existed long before the modern boundaries of the independent states of Laos, Cambodia, Uzbekistan and Kazakhstan were established. The same holds true for Mongolia, Kyrgyzstan and other east and central Asian states. The Vietnamese and the Korean nations were sliced into two separate independent states, but today Vietnam is united as a nation state, but there are still two Korean states. Even India and Pakistan were formed according to the dispersion of the Hindu and the Muslims living in the Indian sub-continent. All these independent states have some - sometimes large to very large - national minorities, which do not see themselves as connected to the dominant nation. Although most of the current boundaries of the Asian states were formed by the European colonial powers, they were drawn according to the dispersion of the dominating nations inhabiting the area. Only Indonesia, which is basically a Muslim country, was established according to the boundaries of the Dutch East India colony. There are, however, some exceptions on the Asian continent, mainly in the Middle East, a situation that will be discussed later.

\section{The Boundaries-Before-Nation Model}

The 'boundaries-before-nation situation' is characteristic of the American and African continents - the New World countries. Thus, the Argentinian and the Canadian nations were created by mingling the people who lived or migrated to an area demarcated by a line. They did not exist as a special nation before. It seems that in all independent countries on the American continent, from Canada to Chile, all of which nowadays try to flaunt their nationhood, no nation as such was in existence before they were created as independent states (Girot 1994). The preColombian map of America has nothing to do with the political map of the American continent of today. There never had been a 'Colombian nation' or a 'Guatemalan' nation before independence (Ireland 1971). The people who lived and are still living between two boundary lines, the northern one with Canada and the southern one with Mexico, created the American Nation. Thus, some of the local tribes and nations, together with new immigrants from all over the world, mingled and created this new American nation. In Africa, the process was somewhat different. With some exceptions, such as Ethiopia and, to some extent, Morocco and Egypt, most of the new African states were created as emerging from the administrative colonial lines, which did not take into consideration the previous existence of nations and tribes. The modern political map of Africa is an outcome of the colonial division of the late nineteenth century, combined with local imperial divisions between mainly the British and the French colonies of Africa (Brownlie 1979). Thus, nearly all African independent states have a multi-national or multi-peoples 
society that is trying to form a unified nation within its boundaries. From South Africa in the south, through Namibia, Zimbabwe, Tanzania, Kenya, Uganda to the Congo, Chad, Mauritania, Ghana and others (Touval 1972), all these countries fit this pattern. The European states of Spain, Belgium, Switzerland, and those of the Middle East, may also fit this model, although they are not situated in the New World realm.

\section{Nations and Boundaries in the Middle East}

The Middle East, apart from Egypt, is in the southwestern part of the Asian continent. As the cradle of civilization, it belongs, in the historical sense, to the Old World. Anyhow, today its nation-boundaries relations fit the New rather than the Old World Model. Until about 150 years ago, the whole area was inhabited mainly by one nation - the Arabs, with some minorities, all under the domination of the Turkish Ottoman Empire. The main exceptions were the Turks, a nation that migrated from central Asia and turned Muslim, and the Persians, another non-Arab Muslim nation. European Mandate regimes, mainly held by Britain and France after the First World War, dictated lines that separated the Middle Eastern Arab nation into different mandate territories, which later became independent states (Biger 2008, 21-32). The mandate powers never considered the initial distribution of the inhabitants of the area, thus creating independent states, none of which had its unique 'old history'. By this process, which took place in the 1920s, the states of Iraq, Lebanon, Syria, Jordan (then called Transjordan) and Palestine (Biger 2004) were created 'out of the blue'. This process led to the creation of the Syrian, the Lebanese, the Jordanian, the Palestinian and the Iraqi nations, which had never existed, as such, before and which were created by the boundaries imposed on the Middle East by the Europeans.

Most of these independent states are now trying to develop their own unique nationhood but it would seem that tribal, religious and other attitudes have prevented them so far from being successful in this. The same holds true for the Palestinians. A true Palestinian is someone who lives, or is a descendant of someone who lived, in the area that Britain created in 1920 and called 'Palestine', a name that did not exist in any formal division of the Ottoman Empire (Biger 1981, 153-160). Those who lived in British Palestine between 1920 and 1947 and their offspring are Palestinians, but they were never united as a nation before Britain created Palestine. Later on, the boundaries in the Arabian Peninsula were established according to the areas ruled by local tribal leaders, not according to any national characteristics (al-Baharam 1975).

\section{The European Case}

Of more than 45 independent states in Europe, only eight are not built around a dominant nation. The others, from the northern Scandinavian states of Iceland, Norway, Sweden, Finland and Denmark to the southern states of Portugal, 
France, Italy, Malta, Greece and others, are 'nation states' built around a dominant nation. The same holds true for most of the west-east axis of Europe, from Ireland, via the Netherlands, Germany, Poland, Latvia, Estonia to Russia, the Ukraine, Belarus, Moldova and Romania. Bulgaria and the other Balkan states of Slovenia, Serbia, Montenegro, Macedonia, Croatia (Englefield 1992), as well as Austria, the Czech Republic, Slovakia and Lithuania, all are nation states. Armenia - the country of the Armenian nation - as well as Georgia, can be included in this model. Many of these countries have some ethnic or even national minorities: the Laps of the north of Norway, Sweden and Finland, the Frisians in the Netherlands, the Austrians in South Tyrol in Italy, the Scots and Welsh in Britain, the Basques and the Corsicans in France, the Hungarians in Romania, the Gypsies, and now also the millions of Muslims living all over Europe. The exception to the model are the five tiny states of Lichtenstein, Luxemburg, Monaco, Andorra (the only country in which Catalan is the official language of the country) and San Marino. These are not classic nation states. All of them were established as a continuation of the old Middle Age regime of an area ruled by a local noble family. Thus, the 30,000 Monegasques of Monaco became a nation of those who lived inside the boundary between Monaco and France, which is one of the oldest boundaries in the world, established in 1070 under the rule of the Grimaldi family (Gonen 1993, 408-409).

The Grand Duchy of Luxemburg was established in 1815 but its boundaries were changed in 1831, after the Belgian revolution, and its final boundaries were established in 1839. The Luxemburgers, who had never been a nation but consist of a mixture of Celtic, Germanic and French origin, became a people with a collective identity, supported by a separate German dialect (Letzeburgish) and later became an independent state, living within the created boundaries (Biger 1995, 277). The story of Liechtenstein began in 1342, when the County of Vaduz became a separate political territory. Its political independence was established in 1806 but its boundaries with Austria and Switzerland were established earlier, in 1719. Thus, the people who lived in that area became a nation, without any pre-characteristics of a nation (Kranz 1981). San Marino, the tiny state located in the Apennine Mountains of central Italy, completely surrounded by Italian territory, was a medieval city state, in which Italian people lived under a special independent regime. Its independence was recognized in 1740 by the Papal State, in 1797 by Napoleon I and by the Congress of Vienna in 1815. Its 25,000 people live in one of the smallest European nations. Andorra, which is situated in the Pyrenean mountain range between France and Spain, which drew its boundaries, was established back in the middle Ages, in 1278, to calm the French-Spanish border area. The 60,000 Andorrans are Roman Catholics and their only unique national characteristic is their language. They use Catalan as their official language, but also speak Spanish and French.

The other three exceptions to the 'nation-before-boundaries' model are Belgium, Switzerland and - to some extent - Spain. Belgium was created in 1830-1831 as a buffer state between Catholic France and the Protestant Netherlands. Thus, it is a two-nation state, in which the Flemish people and the Walloon people, both mainly 
Catholic, live in an independent country, trying to form a national identity out of those who are living within its boundary line, but with a non-predicted future regarding the continuation of this situation. Switzerland was formed back in the middle Ages, on 1 August 1291, when the three forest cantons established an 'eternal alliance'. By 1353, five other cantons had joined the confederacy. All these allies were called Swiss. The 7 million Swiss (Schweizers, Suisses, Svizzeri) are divided among German (70\%), French (20\%), Italian (c. 4\%) and Rheto-Romanche speakers. The Swiss are about evenly divided between Catholics and Protestants. Although they have a long historical tradition, their nationhood was created inside their borders, first established by the 1648 Peace of Westphalia at the end of the Thirty Years' War. The country's present boundaries were established in 1815, at the Congress of Vienna, following the Paris Peace conference of 1814. These boundaries were guaranteed for the first time in the Federal Pact of Zurich in 1815. Thus, the Swiss nation is formed by those who are living within those boundaries. More than 1 million foreigners, mainly Italians, Spaniards and Middle East Muslims, cannot become citizens, even if born in Switzerland (Thürer 1971).

The case of Spain is special. The Spanish state was formed in 1469 by the marriage of Isabella of Castile and Ferdinand of Aragon, and its boundaries with Portugal and France were established in 1297 and 1479 (with Portugal) and in 1659 with France. Thus, Spain's united territory is more than 350 years old. Yet, the 46 million Spaniards (Españoles), which today are overwhelmingly Catholic, have an extremely heterogeneous background. The contemporary Spanish people are composed of the Andalusians, Castilians, Catalans, Galicians, Basques and Gypsies. The Basque people are also resident in southern France, the Gypsies are dispersed all over Europe, the Catalans form the majority of those living in Catalonia but also in Andorra, the Galicians form part of the Portuguese nation, and so only Castilians and Andalusians all live within the boundaries of modern Spain. Thus, although the Spanish nation seems to present one nation, it is in reality an agglomeration of many different peoples living in one united territorial area. As such, it represents the 'boundary-made-nation' category rather than the 'nation-createsboundary' situation.

\section{Conclusion}

Although the model presented above cannot predict much about the future, it highlights the way the independent states of today were established. On the one hand, the European Union is trying to avoid the nation-state idea (ignoring 'Brexit'). On the other hand, nations continue to achieve their independence (East Timor in 2002, Montenegro in 2006, and South Sudan and Kosovo in 2011), and some nations are still trying to achieve independence (Catalonia, Chechnya). With these conflicting trends, one cannot predict the future political map of the world, but, using the models presented above, one may see the way the global political map was established. The notion of the nation state, as a basic model, is well known; but the case of 
the boundaries that created nations is less often discussed. However, the presentation of such a two-way model as has been discussed here may help understand the political map of the world and enlarge our understanding of its fragmented nature.

\section{References}

al-Baharam HM (1975) The Arabian Gulf States: Their Legal and Political Status and Their International Problems. Beirut: Librairie du Liban.

Biger G (1981) Where was Palestine? Pre-World War I perception. Area 13(2), 153-160.

Biger G (1995) The Encyclopedia of International Boundaries. New York: FactsOn-Files.

Biger G (2002) Village boundaries as a factor in delimiting international boundaries in the Middle East. In Schofield C, Newman D, Drysdale A and Brown JA (eds), The Razor's Edge - International Boundaries and Political Geography. London: Kluwer Law International, pp. 463-472.

Biger G (2004) The Boundaries of Modern Palestine. London: Routledge.

Biger G (2008) Britain's role as a boundary maker in the Middle East. In Levey Z and Podeh, E (eds), Britain in the Middle East. Brighton: Sussex Academic Press, pp. 21-32.

Brownlie I (1979) African Boundaries: A Legal and Diplomatic Encyclopedia. London/Los Angeles: C. Hurst.

Brunet-Jailly E (ed.) (2015) Border Disputes, A Global Encyclopedia, Vol. 1. Santa Barbara: ABC-CLIO.

Clarke J (2002) Boundaries as demographic divides. In Schofield C, Newman D, Drysdale A and Brown JA (eds), The Razor's Edge - International Boundaries and Political Geography. London: Kluwer Law International, pp. 259-268.

Curzon of Kedleston G (1907) Frontiers. Oxford: The Clarendon Press.

Englefield G (1992) Yugoslavia, Croatia, Slovenia: Re-Emerging Boundaries, Territory Briefing, 3. Durham: International Boundaries Research Unit - IBRU.

Girot PO (ed.) (1994) World Boundaries, Vol. IV. London; New York: Routledge.

Gonen A (ed.) (1993) The Encyclopedia of the Peoples of the World. New York: H. Holt, pp. 408-409.

Ireland G (1971) Boundaries, Possessions and Conflicts in South America. New York: Octagon Books.

Kranz W (ed.) (1981) The Principality of Liechtenstein. A Documentary Handbook. Vaduz: Information Office of the Government of the Principality of Liechtenstein.

Minogue KR (1967) Nationalism. London: B.T. Batsford.

Muir RE (1975) Modern Political Geography. London: Macmillan Press.

Prescott JRV (1978) Boundaries and Frontiers. London: Allen \& Unwin.

Rebert P (2001) La Gran Linea: Mapping the United States-Mexico Boundary, 1849-1857. Austin: University of Texas Press.

Schofield C, Newman D, Drysdale A and Brown JA (eds) (2002) The Razor's Edge - International Boundaries and Political Geography. London: Kluwer Law International.

Thürer G (1971) Free and Swiss. Translated by Heller RP and Long E. Miami: University of Miami Press.

Touval S (1972) The Boundary Politics of Independent Africa. Cambridge, MA: Harvard University Press.

Waterman S (2002) States of segregation. In Schofield C, Newman D, Drysdale A and Brown JA (eds), The Razor's Edge - International Boundaries and Political Geography. London: Kluwer Law International, pp. 57-76. 


\section{About the Author}

Gideon Biger is Emeritus Professor in the Department of Geography and Human Environment at Tel Aviv University. His areas of interest include historical geography, the history of modern Israel, and political geography. Moreover, he is an expert in international and national boundaries. He is the author of The Boundaries of Modern Palestine, 1840-1947 (2004) and An Empire in the Holy Land: Historical Geography of the British Administration in Palestine, 1917-1929 (1994), among many other publications. 